\title{
Visionary Leadership and Staff Innovative Behaviour in Public Colleges of Education in Kwara State, Nigeria
}

\author{
Abdullahi Nimota Jibola Kadir, Tijani Abdulganiyu Adebayo, Sofoluwe Abayomi \\ Olumide
}

\author{
FACULTY OF EDUCATION, UNIVERSITY OF ILORIN, Nigeria \\ abdullahi.njk@unilorin.edu.ng
}

First draft received: 23 Jul 2019 Date Accepted: 23 Dec 2019 Final proof received: 10 Jan 2020

Abstract
Staff innovative behaviour is critical for organisations if they wish to survive and continue expanding effectively.
This study investigated the effect of visionary leadership on staff innovative behaviour in Kwara State, Nigeria.
The objective of this study is to examine the relationship between visionary leadership and staff innovative
behaviour in Kwara State-owned colleges of education. Quantitative research design was used for the study.
A sample of 220 respondents were randomly selected from the sample colleges of education with the use of
Research Advisor (2006) table to determine sample size of known population. Pearson correlations and linear
regression analysis were used to analyze the collected data. The results show that leadership empowerment,
intellectual stimulation, and adaptivenessness were positively and significantly correlated with staff innovative
behaviour. The result also shows that staff innovative behaviour can be influenced by visionary academic
leaders. It was therefore recommended that academic leaders should continue to boost up the style of
leadership empowerment, intellectual stimulation as well as adaptivenessness towards the realization of staff
innovative behaviour.
Keywords: empowerment; resilience; staff innovative behaviour; visionary leadership
To cite this paper (in APA style):
Jibola Kadir, A. N., Adebayo, T. A., Olumide, S. A. (2020). Visionary leadership and staff innovative behaviour
in public colleges of education in Kwara State, Nigeria. Indonesian Journal of Education, 12(2), 63-72. doi:
10.17509/ije.v12i2.18998.

\section{INTRODUCTION}

Leadership in tertiary institution is considered as the heart of improving staff innovative behaviour. A visionary leader creates changes that happen within the school which will eventually influence the staff innovative behaviour. The effect of falling standard of colleges of education leads to poor quality of output due to continuous strike action, poor leadership, inability to implement change policies, poor supervision corruption, poor commitment and dedication of lecturers to work, poor student attendance at lectures, societal degradation of teaching profession and host of other vices. Therefore, these and many other related issues motivated researchers to examine the effect of visionary leadership on staff innovative behaviour in public colleges of education in Kwara State, Nigeria.

Several studies have been carried out in the area of leadership and innovative behaviour in schools. Mupa
(2015) investigated visionary leadership for the management of innovative higher education institution. Dhammika (2013) conducted one on visionary leadership and organisational commitment, whereas Muhammad (2017) investigated the impact of visionary leadership, learning organisation and innovative behaviour on performance of customs and excise functional. SanchezCardona, Salanova. and Llorens-Gumbau (2018) carried out research on leadership intellectual stimulation and team learning, whereas Peter and Retselisitsoe (2013) focused on leadership organisational citizenship and innovative work behaviour in Lesotho. Finally, Zahari and AbdLatif (2016) investigated the effect of transformational leadership towards teacher innovative behaviour in schools.

Although the effect of different styles of leadership on innovative behaviour has been conducted in the 
previous studies, there is a little, if any, or possibly no research that focused on the effect of visionary leadership on staff innovative behaviour in Nigeria tertiary education. Also, to the researchers' best knowledge, there have been no research in Nigeria so far that have given attention to the empowerment, intellectual stimulation, and adaptiveness as critical indicators to measure visionary leadership as well as using resilience and idea generation as variables to measure staff innovative behaviour. Therefore, this study endeavours to fill the gaps left by the previous scholars.

The following objectives have been formulated to achieve the aim:

1) To examine the level of visionary leadership practice in colleges of education in Kwara State, Nigeria.

2) To determine the level of staff innovative behaviour in colleges of education in Kwara State, Nigeria.

3) To investigate the effect of visionary leadership practice on staff innovative behaviour of colleges of education in Kwara State, Nigeria.

4) To investigate the relationship among empowerment, intellectual stimulation and adaptiveness and staff innovative behaviour of colleges of education in Kwara State, Nigeria.

\section{Visionary Leadership}

Leadership is the process of influencing other members of a group by motivating, inspiring and directing their activities in order to achieve organisational goals (Khanka, 2009). A visionary leader is one who is concerned with how to move an institution from stagnation to an immense innovative system of education (Almog-Bareket, 2012). A visionary leader is also one with strong background with the ability to see the future and to drive the organisation towards success (Senge, 2006). Visionary leadership in this study is seen as a way by which a leader seeks intellectual ways of managing issues and empowering subordinates to develop and apply new ideas in order to achieve the stated goals and objectives.

Empowerment is an integral part of the overall management process in which authority is delegated to subordinate to carry out activities and involve them in decision-making towards improving and realizing organisational objectives. According to Ahmad and Oranye (2010) empowerment is the process of improving self-efficacy, fostering powerlessness and increasing intrinsic forces among organisational members in order to achieve effective goals and objectives. Empowering leaders display confidence in employees' capacity to achieve result, developing self -management skills through delegation of authority and participative decisionmaking as well as ensuring meaningful work environment (Scott, Hui \& Elizebeth, 2013; Ahearne, Mathieu \& Rapp,
2005; Dierendonek \& Dijkstra, 2012; Camps \& Torres, 2011; Seibert, Wang \& Courtright, 2011).

Finally, intellectually stimulating leaders are ones who show the degree to which they provide encouragement to their subordinates to seek intellectual ways of solving problems and analyzing situation for the benefit of organisation (Dhammika, 2013). Intellectually stimulating leaders involve employees in the activities which lead them to be creative and innovative (Moss \& Ritossa, 2007). Ogala, Skalieh, and Linge (2017) assert that intellectual stimulation enhances effective development of employee commitment to the organisation.

\section{Staff Innovative Behaviour}

Staff innovative behaviour involves generation, realization and promotion of new knowledge, skill, and ideas to maximize performance of a group and work role for an organisation. Innovative behaviour is important for all staff in tertiary institutions to meet the present and future educational needs of the modern climate (Jamssen, 2005). Staff innovative behaviour can be viewed as the intentional and application of new idea with a work role in order to benefit the organisation (Jamssen, 2000). Staff innovative behaviour in this study is measured in terms of resilience and idea generation.

McLarnon and Rothostein (2013) view resilience as a dispositional variable linked to positive self-regulatory and coping functions of employee in an organisation. Resilience is defined as a psychological device that enable people to recover from traumatic events. This implies the individual psychological ability to deal with stress in an environment. Resilience can be enhanced directly through empowering leadership behaviour. Mumford (2000) sees idea generation as the realization of something new in solving a problem. This implies that he referred to idea generation as the ability to create new knowledge and skill or construct new way of addressing an issue towards the achievement of organizational objectives. Idea generation staff are individuals who can approach an issue from a different way.

\section{Theoretical Framework}

The theoretical framework was based on transformational leadership that was posited by Slocum and Hellriegel (2007). They explained the components of transformational leadership through the dimensions of showing consideration of individual-based support, building intellectual stimulation, motivation and building creative culture, and developing structures. This implies that a leader can influence his/her followers through the leadership behaviour s/he has adopted. Transformational leadership style involves behaviours that become exemplary in planning the future of the institution, inspiring staff on the matters relating to innovation and creativity. 
The framework can also be applied to the school system. Administrators can build a conducive working environment by being sensitive to the needs of its target audience and providing appropriate training for staff development. Intellectually stimulating leader may also encourage his/her staff to think creatively in solving problems. In addition, an adaptive leader shows the level of moral and ethics in his/her dealing and promoting cooperation among staff. This study is anchored on transformational leadership theory because it focuses on the important requirement of a leader in managing the organisation to create new ideas that are creative and innovative towards achieving the stated goals. It also considered leader as a person that can change important aspects in the organisation through vision action and influence.

\section{METHOD}

\section{Research Design}

The quantitative research design was used in this study. The design was considered appropriate because it will enable the researcher to determine the interaction that exists among leadership integrity, power sharing, fairness and staff innovative behaviour. It also gives opportunity to obtain opinion of the sample population, analyze the data collected with the use of appropriate data analysis technique and reach a reasonable conclusion about the population from the findings of the study (Mayer, 2013).

\section{Population and Sampling}

The population of this study comprises the administrative and teaching staff in three Kwara State-owned colleges of education, Nigeria. The target population comprised 30 administrators and 428 academic staff. The sample of 15 administrators and 205 academic staff were selected with the use of Research Advisor (2006) table of determining the sample size of known population. Multi- stage sampling technique was used in selecting the respondents in 3 Kwara State owned colleges of education. Purposive sampling technique was used to select 5 administrators in each college of education. Proportional sampling method was used to select 94 out of 197 academic staff in Kwara State college of education, llorin, 59 out of 123 academic staff in Kwara State college of education, Oro and 52 out of 108 academic staff in Kwara State college of education (Technical) Lafiaji. Stratified random sampling technique was used to select the sample of 220 respondents, in order to ensure that every member of the population has equal rights and chance of being selected. The procedure thus ensured that all categories of staff in the university are represented in this study (Creswell \& Creswell, 2017).

\section{Instrument}

The research instrument for the present study comprised an adapted questionnaire from earlier studies by Shahab, Sobari and Udin (2018) on empowerment and Ogala, Sikalieh and Linge (2017) on intellectual stimulation and adaptivenessness under visionary leadership. A total number of 35 items were used to measure visionary leadership with three subscales: empowerment (12 items), intellectual stimulation (11 items) and adaptiveness (12 items). The items of questionnaire regarding staff innovative behaviour were concluded from King (2010) on resilience, Mumford (2000) on idea generation, also Zhou and George (2001) on staff tolerance of ambiguity. It comprised 25 items with three components; resilience (10 items), idea generation (5 items) and tolerance of ambiguity ( 10 items). The instrument utilized a five-point Likert scale ( $5=$ strongly agree; 4 = agree; 3 = neutral; 2 disagree; 1 = strongly disagree).

\section{Reliability and Validity}

Cronbach's alpha was used to test the reliability of the items. As shown in Table 1, the value for Cronbach's alpha for this study was proven to be reliable.

Table 1

Reliability test for Visionary Leadership

\begin{tabular}{llcl}
\hline Variables & No of Items & Cronbach's Alpha & Decision \\
\hline Empowerment & 12 & 0.82 & All items are reliable \\
\hline Intellectual Stimulation & 11 & 0.78 & All items are reliable \\
\hline Adaptiveness & 12 & 0.84 & All items are reliable \\
\hline
\end{tabular}

Table 1 shows that there are 12 items under empowerment of visionary leadership. The value of the Cronbach's alpha for these 12 items is 0.82 . Furthermore, there are 11 items under intellectual stimulation with Cronbach's alpha of 0.78 and 12 items of adaptiveness with Cronbach's alpha of 0.84 . According to George and Mallery (2001), values above .7 are considered reliable and values above .8 are preferable and represent a good reliability. The Cronbach's Alpha values for all the 3 indicators of visionary leadership were around 0.80 . Therefore, the values show very good internal consistency reliability for scale and all the 35 items in the questionnaire are found to be reliable. 
The three main indicators of staff innovative behaviour are resilience, idea generation, and tolerance of ambiguity to measure staff innovative behaviour. The Cronbach's value for resilience is 0.76 for 10 number of items. In addition, 5 items from idea generation of staff innovative behaviour have Cronbach's alpha of 0.78 and 10 items from tolerance of ambiguity has Cronbach's alpha of 0.82 . Therefore, all instrument items for staff innovative behaviour used in this study are reliable. The instrument was validated by two experts in the department of educational management and two experts in test and Measurement in faculty of education, University of Ilorin, Nigeria. The amendment of items by rephrasing the statement was done according to opinions from four academic staff who reviewed the instrument.

\section{Data Collection Process}

The data were collected from respondents (administrators \& academic staff) using questionnaire. The questionnaires were distributed to respondents with the help of three trained research assistants. To guarantee optimal response rate, the objectives of the research and instructions on how to respond to questions were clearly explained to respondents. This effort enhanced full participation of the respondents. The exercise of data collection was smoothly completed within two weeks since questionnaires were personally administered by researchers, trained research assistants and with the help of colleagues in the three Kwara Stateowned colleges of education.

\section{Data Analysis}

Data collected for this study were analysed using descriptive and inferential analysis techniques. Statistical Package for Social Sciences (SPSS version 23) was used for statistical analysis. Descriptive statistics using mean and standard deviation was used to answer the research objectives which are aimed at analyzing academic staff perception on visionary leadership based on three sub constructs namely empowerment, intellectual stimulation and adaptiveness while the second objective was aimed at analyzing administrators' perception on staff innovative behaviour based on three sub constructs of resilience, ideas generation and tolerance of ambiguity. On the other hand, Pearson product moment correlation statistical and linear regression analysis were used to test the hypotheses.

\section{RESULTS}

This section presents a comprehensive result of the analysis made from the data collected in this study. It starts with an analysis of the demographic information of respondents who participated using descriptive statistics.

\section{Demographic Profile of Respondents}

Table 2

Demographic Profile of the Respondents

\begin{tabular}{llll}
\hline & & $\mathrm{N}=220$ & Percentage (\%) \\
\hline Gender: & Female & 98 & $44.5 \%$ \\
& Male & 122 & $55.5 \%$ \\
\hline Age: & $21-30$ & 220 & $100 \%$ \\
& $31-40$ & 34 & $15.5 \%$ \\
& $41-50$ & 140 & $63.6 \%$ \\
& 51 above & 30 & $13.6 \%$ \\
\hline & & 16 & $7.3 \%$ \\
\hline Qualification: & HND & 220 & $100 \%$ \\
& Bachelor's degree & 05 & $2.3 \%$ \\
& Master's degree & 130 & $59 \%$ \\
& Ph.D. & 05 & $36.4 \%$ \\
& & 220 & $2.3 \%$ \\
\hline Year of Experience & $1-5$ years & 28 & $100 \%$ \\
& $6-10$ years & 68 & $12.7 \%$ \\
& $11-15$ years & 92 & $30.9 \%$ \\
& $16-20$ years & 20 & $41.8 \%$ \\
& 21 years above & 12 & $9.1 \%$ \\
& & 220 & $5.5 \%$ \\
\hline
\end{tabular}

Table 2 shows the demographic information of respondents that participated in this study. From the table, 98 respondents (44.5\%) are female and 122 respondents are male (55.5\%). In terms of average age of the respondents, majority (140) of the respondents $(63.6 \%)$ are between ages $31-40$ years. Based on qualification of the respondents, majority (130 respondents or $59 \%$ ) are bachelor's degree holders while $5(2.3 \%)$ are PhD holders. In the aspect of year of experience, the majority (92 respondents or $41.8 \%$ ) have $11-15$ years of experience, while 12 respondents (5.5\%) have over 20 years' experience in the sample university. 


\section{Level of Visionary Leadership}

Table 4 presents the mean and standard deviation for each measurement of visionary leadership and overall result for level of visionary leadership practice.

Table 3

Level of Visionary Leadership Practice

\begin{tabular}{lccc}
\multicolumn{1}{c}{ Variables } & Mean & Standard Deviation & Level \\
\hline level of Empowerment & 2.95 & 0.968 & Moderate \\
Level of Intellectual Stimulation & 2.92 & 0.967 & Moderate \\
Level of Adaptiveness & 2.93 & 0.966 & Moderate \\
\hline Overall Level Visionary Leadership Practice & 2.93 & 0,967 & Moderate \\
\hline
\end{tabular}

Table 3 shows that the overall level of visionary leadership practice is moderate with mean score of 2.93 and standard deviation of .967. This indicated that most of the staff perceive their leaders as giving them a moderate level of visionary behaviour in terms of empowerment, intellectual stimulation and adaptiveness in Kwara State owned colleges of education.

Level of Staff Innovative Behaviour

This section explains the mean and standard deviation value that shows the level of staff innovative behaviour.

Table 4

Level of Staff Innovative Behaviour

\begin{tabular}{lccc}
\multicolumn{1}{c}{ Variables } & Mean & Standard Deviation & Level \\
\hline Level of resilience & 2.92 & 0.966 & Moderate \\
Level of ideas generation & 2.86 & 0.984 & Moderate \\
Level of tolerance of ambiguity & 2.93 & 0.970 & Moderate \\
\hline Overall Level of Staff Innovative & 2.90 & 0.973 & Moderate \\
Behaviour & & & \\
\hline
\end{tabular}

The analysis presented in table 4 presents the mean and standard deviations for all levels of staff innovative behaviour in terms of resilience, idea generation, and tolerance of ambiguity. The overall result of staff innovative behaviour is at moderate level (Mean $=2.92$, $\mathrm{SD}=0.973$ )

\section{Hypotheses Testing}

Ho1: There is no significant relationship between empowerment leadership and staff innovative behaviour.

$\mathrm{H}_{\circ 2}$ : There is no significant relationship between intellectual stimulation leadership and staff innovative behaviour.
Ho3: $\quad$ There is no significant relationship between adaptiveness leadership and staff innovative behaviour.

Ho4: There is no significant relationship among empowerment, intellectual stimulation and adaptiveness and staff innovative behaviour.

Pearson product moment correlation statistic was used to analyze the relationship between independent and dependent variables.

Ho1: There is no significant relationship between empowerment leadership and staff innovative behaviour.

Table 5

Correlational Analysis for Empowerment Leadership and Staff Innovative Behaviour

\begin{tabular}{|c|c|c|c|}
\hline Empowerment & & Empowerment & Staff Innovative Behavior \\
\hline \multirow[t]{3}{*}{ Empowerment } & Pearson correlation & 1 & $.830^{\star \star}$ \\
\hline & $\begin{array}{l}\text { Sig. } \\
\text { (2-tailed) }\end{array}$ & & .000 \\
\hline & $\mathrm{N}$ & 220 & 220 \\
\hline $\begin{array}{l}\text { Staff } \\
\text { Behaviour }\end{array}$ & Pearson Correlation & $.830^{\star *}$ & 1 \\
\hline 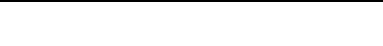 & Sig. & .000 & \\
\hline
\end{tabular}




$\begin{array}{lll}\mathrm{N} & 220 & 220\end{array}$

Table 5 indicates that empowerment has a significant and positive relationship with staff innovative behaviour with calculated $R$-value $=.830 ; p<.000$. This shows that there is a significant and positive relationship between empowerment leadership and staff innovative behaviour in Kwara State owned colleges of education. Therefore, the hypothesis which state that there is no significant relationship between empowerment leadership and staff innovative behaviour is rejected.

Ho2: There is no significant relationship between intellectual stimulation leadership and staff innovative behaviour.

Table 6

Correlational Analysis for Intellectual Stimulation Leadership and Staff Innovative Behaviour Intellectual Stimulation Staff Innovative Behavior

\begin{tabular}{|c|c|c|c|}
\hline \multirow[t]{3}{*}{ Intellectual Stimulation } & Pearson Correlation & 1 & $.870^{\star \star}$ \\
\hline & $\begin{array}{l}\text { Sig. } \\
\text { (2-tailed) }\end{array}$ & & .000 \\
\hline & $\mathrm{N}$ & 220 & 220 \\
\hline \multirow[t]{3}{*}{$\begin{array}{l}\text { Staff } \\
\text { Behaviour }\end{array}$} & Pearson Correlation & $.870^{* *}$ & 1 \\
\hline & $\begin{array}{l}\text { Sig. } \\
\text { (2-tailed) }\end{array}$ & .000 & \\
\hline & $\mathrm{N}$ & 220 & 220 \\
\hline
\end{tabular}

Table 6 indicates that intellectual stimulation leadership has a significant and positive relationship with staff innovative behaviour with calculated $r$-value $=.870$; $p<.000$. This shows that there is a significant and positive relationship between intellectual stimulation leadership and staff innovative behaviour in Kwara State owned colleges of education. Therefore, the hypothesis which state that there is no significant relationship between intellectual stimulation leadership and staff innovative behaviour is rejected.

Но3: $\quad$ There is no significant relationship between adaptiveness leadership and staff innovative behaviour.

Table 7

Correlational Analysis for Adaptiveness Leadership and Staff Innovative Behaviour

\begin{tabular}{|c|c|c|c|}
\hline & & Adaptiveness & Staff Innovative Behaviour \\
\hline \multirow[t]{3}{*}{ Adaptiveness } & Pearson Correlation & 1 & $.679^{\star \star}$ \\
\hline & $\begin{array}{l}\text { sig. } \\
\text { (2-tailed) }\end{array}$ & & .000 \\
\hline & $\mathrm{N}$ & 220 & 220 \\
\hline \multirow[t]{3}{*}{$\begin{array}{l}\text { Staff } \\
\text { Behaviour }\end{array}$} & Pearson Correlation & $.679^{* *}$ & 1 \\
\hline & $\begin{array}{l}\text { Sig. } \\
\text { (2-tailed) }\end{array}$ & .000 & \\
\hline & $\mathrm{N}$ & 220 & 220 \\
\hline
\end{tabular}

Table 7 indicates that adaptiveness leadership has a significant and positive relationship with staff innovative behaviour with calculated $r$-value $=.679 ; p<.000$. This shows that there is a significant and positive relationship between adaptiveness leadership and staff innovative behaviour in Kwara State owned colleges of education. Therefore, the hypothesis which state that there is no significant relationship between adaptiveness leadership and staff innovative behaviour is rejected.

Ho4: There is no significant relationship among empowerment, intellectual stimulation and adaptiveness and staff innovative behaviour of colleges of education in Kwara State, Nigeria

Table 8

Linear Regression Analysis

This part explains the linear regression finding that measures the visionary leadership practice variables on staff innovative behaviour in colleges of education in Kwara State, Nigeria. 
Table 8

Linear Regression of visionary Leadership and Staff Innovative Behaviour

\begin{tabular}{lllll}
\hline Model & $\mathbf{R}$ & R Square & Adjusted R Square & Std. Error of the Estimate \\
\hline 1 & 0.113 & 0.602 & 0.589 & 0.384 \\
\hline
\end{tabular}

a. Predictors: (constant), Empowerment, Intellectual Stimulation, Adaptivenes

Table 8 shows the value of visionary leadership on staff innovative behaviour. Regarding of $R$ Square value that ethical leadership practice has effect on staff innovative behaviour with 85.4 by staff regarding of $R$ square value from the table. Therefore, the result showed that visionary leadership practiced by the administrators can give effect on staff innovative behaviours.

Table 9

Linear Regression Coefficients for Visionary Leadership and Staff Innovative Behaviour

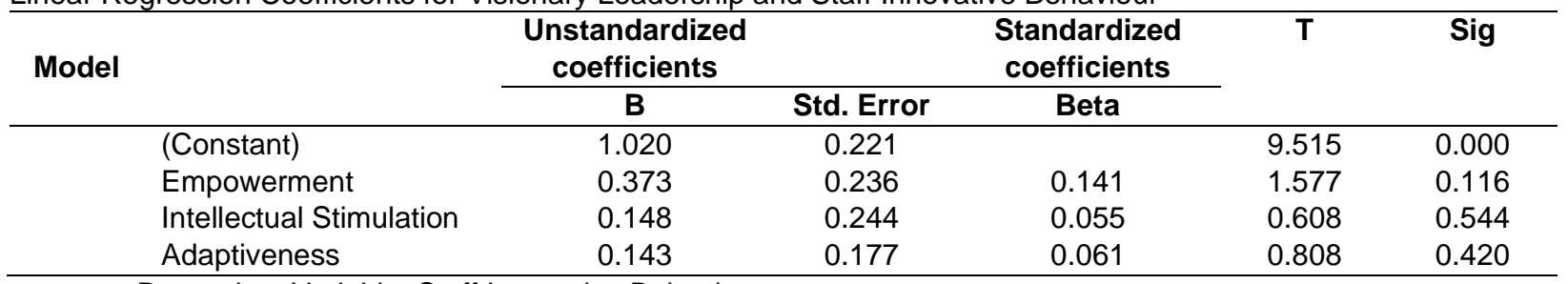

a. Dependent Variable: Staff Innovative Behaviour

Table 9 displays results of linear regression model, in which standard regression weight of the beta coefficient value for visionary leadership was 1.020 which indicated that the increase in visionary leadership practice by administrators is responsible for an increase in staff innovative behaviour. The results also show that visionary leadership and staff innovative behaviour were positively related. $T$-test of 9.515 was sufficiently high with corresponding $p$-value of 0.000 . Thus, in comparison, empowerment has the highest effect (Beta=0.141) followed by adaptiveness (Beta=0.061) and intellectual stimulation (Beta=0.055). In summary, there is positive and significant relationship among visionary leadership in terms of empowerment, intellectual stimulation, adaptiveness and staff innovative behaviour.

\section{DISCUSSION}

The results of this study highlighted the moderate level for empowerment, intellectual stimulation and adaptiveness, based on the perception of respondents. The aim of colleges of education is to develop and impact proper values for the survival of the citizens and society. Thus, it is the responsibility of administrators to display fearlessness and energizing vision that will invigorate innovative behaviour among staff.

The results of this study revealed that leadership empowerment has enormous impact on staff innovative behaviour. This implies that a visionary leader provides opportunity for learning and professional development and incentive system to promote the behaviours necessary to implement their strategic vision, delegates and distributes assignment as a way of empowering staff, provides appropriate guidance and direction based on people's capacities, fosters a sense of purpose, and helps staff find meaning in their work as well as promoting a sense of control and self-confidence in staff. This study supports the claims of Madhavan (2014), Berraies, Chaher, and Benyahia (2014), Mushipe (2011) amd Hamad (2010) who emphasized that there is a strong and positive relationship between empowerment and employees' innovative behaviour. In addition, the results correspond with the position of Ahearne, Mathieu and Rapp (2005) that leadership empowerment has great influence on peoples' satisfaction and performance.

The result of second hypothesis testing shows that leadership intellectual stimulation has a significant relationship with staff innovative behaviour. This result shows that intellectually stimulating leaders who develop those values that will strengthen institution functioning, change institution culture by implementing new ideas, as well as stimulating staff to challenge assumption and see the world in new ways, tend to improve staff innovative behaviour. This result conforms that of Cheung and Wong (2011) who found that intellectual stimulating leadership style energises employees to seek innovative approaches to their work. This result further agrees with Sauchez-Cardona, Salanova and Llorens-Gumbau (2018) that there is a strong relationship and effect that intellectual has on team learning and team position. Finally, the result concurs with Masi and Cooke (2000) who found that intellectually stimulating leadership style of managers led to employees being more innovative, committed and less stressed in dealing with organisational growth.

However, this finding disagreed with Janssi and Dionne (2003) as well as Wilson-Evered, Dall and Neale (2001) who found that intellectually stimulating leadership style has negative effect on staff innovative behaviour in an organisation. Similar disagreement is also found with the result of Choi, Wan-Mardhia, Tan and Low (2014) who argued that there is no significant 
relationship between intellectual stimulation and employee job satisfaction.

The result from hypothesis three revealed that adaptiveness leadership has a positive effect on staff innovative behaviour. This implies that whenever the leader stays optimistic and uses positive message in achieving organisational goals, displays flexible problemsolving styles, acts differently in relation to circumstances, maintains definite standard of performance as well as demonstrates interpersonal adaptability in order to create an enduring institution that continues to operate efficiently and effectively for long period of time tend to enhance staff innovative behaviour. This finding is in line with Coulombe (2015) that adaptiveness and leadership skills are key elements of organisational innovation.

Finally, the result of regression analysis revealed that there is a positive relationship between visionary leadership and staff innovative behaviour in colleges of education in Kwara State, Nigeria. This is an indication that improvement on the indices (empowerment, intellectual stimulation and adaptiveness) of visionary leadership in managing colleges of education has a positive chance of achieving staff innovative behaviour. The finding of this study conforms to Muhammad (2017) that visionary leadership has a direct and strong effect on staff innovative behaviour. Research has consistently shown that staff can produce better results provided they are well led (Bello, 2012). Adebayo, Simin and Megat (2018) considered leadership style as a major influence on the performance of organizations, and staff. This implies that qualities and behaviours displayed by the leader fosters and encourages staff innovative behaviour.

\section{CONCLUSION \& RECOMMENDATIONS}

The results of this study will be of benefit to academic leaders, staff, government and stakeholders of education. The practical implication of this study includes revealing visionary leadership indicators that can influence staff innovative behaviour. The research shows that visionary leadership enhances staff innovative behaviour. This finding may also help academic leaders, government, and stakeholders to review their behavioural style as they could be mindful of which indicators from visionary leadership are suitable in dealing with staff in order to improve innovative behaviour. Furthermore, this study would encourage lecturers to recognize their crucial parts in supporting the leaders to be effective in visionary leadership towards having positive standard and significant effect on innovative behaviour.

Based on the findings, it is recommended that academic leaders continue to boost up the style of leadership empowerment by providing a supportive and encouraging environment of work, opportunity for learning and professional development, incentive system to promote the behaviours necessary to implement their strategic vision, delegate and distribute assignment as a way of empowering staff, provides appropriate guidance and direction based on people's capacities, fostering a sense of purpose and helping staff find meaning in their work as well as promoting a sense of control and selfconfidence in staff. In addition, leaders should improve strategic thinking skills (intellectually stimulating skills) by motivating the employees on creativity, innovation, improvement, development and learning, stimulate staff to challenge assumption and see the world in new ways in order to continue to improve staff innovative behaviour. Furthermore, leaders should continue to establish and display flexible problem-solving styles, act differently in relation to circumstances, maintain definite standard of performance as well as demonstrating interpersonal adaptability in order to create an enduring institution that continues to operate efficiently and effectively for long period of time towards enhancing staff innovative behaviour. Visionary leadership is a sure way to prepare staff for effective resilience, tolerance of ambiguity and idea generation in order to give room for new development and achievement of educational goals and objectives.

\section{REFERENCES}

Adebayo, S. A., Simin, G. \& Megat, A. (2018). Leadership and staff organizational citizenship behaviour in higher education institutions: A quantitative Analysis. Malaysian Online Journal of Educational Management, 6(1), 36-52.

Ahearne, M., Mathieu, J., \& Rapp, A. (2005). To empower or not to empower your sales force? An empirical examination of the influence of leadership empowerment behaviour on customer satisfaction and performance. Journal of Applied Psychology, 9(5), 945-955. doi.10.1037/0021-9010-945-955.

Ahmad, N. \& Oranye, N. O. (2010). Empowerment, job satisfaction and organisational commitment: A comparative analysis of nurses working in Malaysia and England. Journal of Nursing Management, $\quad$ 18(5), $582-591$. https://doi.org/10.1111/j.13652834.2010.01093.x

Al-Khasawneh, A. L. (2013). Effect of organisational climate on job turnover of employees at tourism hotels in Petra region of Jordan. American Journal of Social Management Sciences, 4(2), 54-62. https://doi/10.525//ajsms.2013.42.54.62.

Almog-Bareket, G. (2012). Visionary leadership in business schools: An institutional framework. Journal of Management Development, 31(4), 431440. https://doi.org/10.1108/02621711211219086

Bello, S. M. (2012). Impact of ethical leadership in employee job performance. International Journal of Business and Social Science, 3(11), 228-236.

Berraies, S., Chaher, M. \& Benyahia, K. (2014). Employee empowerment and it's important for trust innovation and organisational performance. Business Management and Strategy, 5(2), 82103. https://doi.org/10.5296/bms.v5i2.6558 
Camps, J. \& Torres, F. (2011). Contingent reward leader behaviour: Where does it come from? System Research and Behavioural Sciences, 28(3), 212230. https://doi.org/10.1002/sres.1067

Cheung, A. C. K. \& Wong, P. M. (2011). Effects of school heads and teachers' agreement with the curriculum reform on curriculum development progress and student learning in Horgkong, International Journal of Educational Management, 25(5), 453-473. doi 10-1002/sres.1067

Choi, S. L., Wan-Mardhia, M. Y., \& Low, H. H. (2014). The impact of transformational leadership style on job satisfaction. World Applied Sciences journal, 29(1), 117-124.

Coulombe, C. (2015). Innovation, adaptiveness leadership and project management. Review of Integrative Business and Economics Research, 4(4), 225-236.

Creswell, J. W., \& Creswell, J. D. (2017). Research design: Qualitative, quantitative, and mixed methods approaches. Los Angeles, CA, USA: Sage Publications.

Dhammika, K. A. S. (2013). Visionary leadership and organisational commitment: The mediating effect of leader member exchange. Wayamba Journal of Management, 4(1), 1-10. https://doi.org/10.4038/wjm.v4i1.7452

Dierendonek, D. \& Dijkstra, M. (2012). The role of the followers in the relationship between empowering leadership and empowerment: A longitudinal investigation. Journal of Applied Social Psychology, 42(1), E1-E20. doi:10.1111/j.15591816.2012.01022.x

George, D. \& Mallery, P. (2001). SPSS for windows step by step: A simple guide and reference ( $3^{\text {rd }}$. Eds). Boston, MA, USA: Allyn and Bacon.

Hamad, S. S. (2010). Antecedents and consequences of employees' empowerment. Management review: An international journal, 5(1), 64-94.

Janssen, O. (2000). Job demand perceptions of effort reward, fairness and innovative work behaviour. Journal of Occupational and Organisational Psychology, 73, 287-302.

Janssen, O. (2005). The impact of perceived influence and supervisor supportiveness on employee innovative behaviour. Journal of Occupational and Organisational Psychology, 78(4), 573-579.

Janssi, K. S. \& Dionne, S. D. (2003). Leading for creativity: The role of unconventional leader behaviour. Leadership Quarterly, 14, 475-498.

Khanka, S. S. (2009). Organisational behaviour. Ram Nagor-New Delhi, India: S. Chand and Company Ltd.

King, G. A. (2010). Resilience and leadership: The selfmanagement of failure (M. G. Rothstein, Ed.). In M. G. Rothstein \& R. J. Burke (Eds.), New horizons in management: Self-management and leadership development (pp. 361-394). Edward Elgar Publishing. https://doi.org/10.4337/9781849805551.00021
Madhavan, N. (2014). Employees' empowerment towards innovation. Review of Literature, 2(2), 16.

Masi, R. T., \& Cooke, R. A. (2000). Effects of transformational leadership on subordinate motivation, empowering, norms and organisational productivity. The International Journal of Organisational Analyses, 8(9), 16-47.

Mayer, A. (2013). Introduction to statistics and SPSS in psychology ( $1^{\text {st }}$ ed.). London, England: Pearson Education Limited.

Mclarnon, M. J. W. \& Rothstein, M. G. (2013). Development and initial validation of the workplace resilience inventory. Journal of Personnel Psychology, 12(3), 63-73 doi:10.1027/1866-5888/a000084.

Moss, S. A., \& Ritossa, D. A. (2007). The impact of good orientation on the association between leadership style and follower performance, creativity and work attitude. Leadership Journal, 3(4), 433-456.

Muhammad, A. (2017). The impact of visionary leadership, learning organisation and innovative behaviour to performance of customs and excise functional. International Journal of Human Capital Management, 1(2), 52-60. https://doi.org/10.21009/IJHCM.012.07

Mumford, M. D. (2000). Managing creative people: Strategies and factics for innovation. Human Resources Management Review, 10(3), 313-351. https://doi.org/10.1016/S1053-4822(99)00043-1

Mupa, P. (2015). Visionary leadership for management of innovative higher education institutions: leadership trajectories in a changing environment. Research on Humanities and Social Sciences, 5(13), 43-50.

Mushipe, Z. J. (2011). Employee empowerment and job satisfaction: A study of the employees in the food manufacturing sector in Zimbabwe. Interdisciplinary Journal of Contemporary in Business, 3(8), 18-41.

Ogala, M. G. O., Sikailieh, D. \& Linge, T. (2017). The influence of intellectual stimulation leadership behaviour on employee performance in SME in Kenya. International Journal of Business and Social Science, 8(3), 89-99.

Peter, P. K. \& Retselisitsoe, L. S. (2013). Leadership organisational citizenship and innovative work behaviours in Lesotho: Exploratory evidence. Journal of Language, Technology and Entrepreneurship in African, 4(2), 46-58.

Research Advisor (2006). Sample size table. http://www.research-advisor.com

Wilson-Evered, E., Dall, P. \& Neale, M. (2001). The influence of leadership on innovation at work. In Parry, K. W. (Ed.). Leadership in the Antipodes: Findings, Implications and a Leader Profile. News Zealand: Victoria University of Wellington. Pp. 4677.

Sanchez-Cardona, I., Salanova, M., \& Llorens-Gumbau, S. (2018). Leadership intellectual stimulation and 
team learning: The mediating role of team positive effect. Universitas Psychologica, 17(1), 1-16. https://doi.org/10.11144/javeriana.upsy17-List.

Scott, L. M., Hui, L., \& Elizabeth, M. C. (2013). Directive versus empowering leadership: A field experiment comparing impact on task proficiency and proactivity. Academy of Management Journal, 56(5),

1372-1382 https://doi.org/10.5465/amj.2011.0113

Seibert, S. E., Wang, G. M. Courtright, S. H. (2011). Antecedents and consequences psychological and team empowerment in organisations: a metaanalytic review. Journal of Applied Psychology, 96(5), 981-990. doi:10.1037/a002676.

Senge, P. (2006). Shared vision. In P. Senge, (Ed.) the fifty disciplines. The art and practice of the learning organisation. Bantam-Doubleday, New York, NY, pp. 205-232.

Shahab, M. D., Sobari, A. \& Udim, U. (2018). Empowering leadership and organisation citizenship behaviour: the mediating roles of psychological empowerment and emotional intelligence in medical service industry. International Journal of economics and Business Administration, 6(3), 80-91. https://doi.org/10.35808/ijeba/165

Slocum, J. W., \& Hellriegel, D. (2007). Fundamental of organisational behaviour. Belmont: Thomson he multifactor leadership questionnaire. Redwood City, CA, USA: Mind Garden.

Zahari, A. \& AbdLatif, K. (2016). Conducted the effect of transformational leadership towards teacher innovative behaviour in schools. International Journal of Scientific and Research Publications, 6(5), 283-286.

Zhou, J. \& George, J. M. (2001). When job dissatisfaction leads to creativity: Encouraging the expression of voice. Academic Management Journal, 44, 682696. 